\title{
YTHDF2 Gene
}

National Cancer Institute

\section{Source}

National Cancer Institute. YTHDF2 Gene. NCI Thesaurus. Code C97999.

This gene may be involved in both signaling and humoral immunity. 